\section{Effects on biological evolution of changes in ocean chemistry}

Perhaps the most perplexing problem of biological evolution involves explanation of why diversification of life began only after $85 \%$ of the lifetime of the Earth while simple life seems to have been present for virtually all of geological time. Recent observations $\mathrm{s}^{1-2}$ on the presence of complex organic species in meteoritic debris and in the interstellar medium show that some of the basic biological building blocks may have been available from the earliest times. Chamberlain and Marland ${ }^{3}$ have commented on the biological consequences of the Hargraves ${ }^{4}$ model of ocean-crust evolution while others ${ }^{5-6}$ have reassessed evidence on atmospheric evolution and indicated that changes in oxygen partial pressure may not have been critical to the diversification of life. In this note I suggest that important changes in ocean chemistry must have occurred if our current models of crustal evolution and igneous events have any validity. The evolution of complex life forms requires a high degree of environmental stability and constancy of chemical environment. It is suggested that this condition is closely linked to the spacing of major volcanic centres, and that the modern long wavelength pattern of ocean ridges and subduction zones was necessary to achieve this stability. The distribution of ophiolites or ocean-floor structures of modern type ${ }^{7}$ indicates that the present pattern may have been initiated about one billion years ago. Furthermore, large scale continental emergence ${ }^{4}$ may have been necessary to provide oceans with stable chemistry.

There is much evidence to support the Hargraves ${ }^{4}$ model of early globe-encircling oceans and slow continental emergence. The ocean mass may have been greater $^{8}$. Further evidence shows that with an early hotter earth, volcanic activity was more intense and that centres of volcanic activity were closely spaced with a wavelength pattern of hundreds not thousands of kilometres. We also know that the cooling of submarine igneous bodies involves convective flow of seawater and that the chemistry of the cold inflow and hotter discharge waters is quite different. Thus, early oceans would tend to reflect volcanogenic discharge more than continental runoff. As such, chemistry would be erratic and frequently concentrations of typical easily transported metals like $\mathrm{Cu}, \mathrm{Hg}, \mathrm{Pb}, \mathrm{Zn}, \mathrm{Mn}, \mathrm{Fe}, \mathrm{As}$, could be large as in the modern Red Sea deeps. (The Red Sea illustrates ${ }^{9}$ the toxic effects of such discharge.)

For the present earth, continental runoff amounts to about $3 \times 10^{19} \mathrm{~g} \mathrm{yr}^{-1}$ while the ocean mass is $1.4 \times 10^{24} \mathrm{~g}$. Submarine volcanic activity associated with the ocean-floor spreading process currently adds some $3 \times 10^{16} \mathrm{~g}$ of basalt liquids to the ocean annually. This liquid at $1,200^{\circ} \mathrm{C}$ cools by convective flow of ocean water. Sites of discharge will cause local changes in chemistry as seen in the Red Sea and many other places ${ }^{10,11}$. The energy input at modern ocean ridges $\left(4 \times 10^{19} \mathrm{~J} \mathrm{yr}^{-1}\right)$ could heat $10^{17} \mathrm{~g}$ of sea water to $100^{\circ} \mathrm{C}$. Thus, at present, hydrothermally modified ocean water might approach $1 \%$ of the volume of continental runoff. If this water contains any chemical species at much higher concentrations than in river water, it may influence the balance of ocean waters.

Elements that are present at much higher levels than in normal ground waters (100 times) include a host of those which can be toxic to complex life forms ( $\mathrm{As}, \mathrm{Hg}, \mathrm{Cu}, \mathrm{Zn}$, $\mathrm{Mn}, \mathrm{Fe}, \mathrm{Pb}$ ). Furthermore, if there was little land above sea level in the Archaean, the input of metal absorbing clay mineral would be reduced, and this detoxification process would be less effective ${ }^{12}$.

At present, while basaltic mantle-derived volcanic processes are concentrated in the submarine environment, subduction andesite-granite igneous activity is concentrated on the continents and if convective cooling occurs, it involves less saline waters which in general transport less metal. But in the Archaean, nearly all igneous activity was submarine. The huge granite bodies of the Archaean could generate sustained submarine discharge on a scale not seen today. Imagine the consequences of emplacing the Sierra Nevada Batholith in a submarine environment.

Thus, the Archaean ocean floor may have been populated by closely spaced volcanic centres with an igneous intensity an order of magnitude more than known today ${ }^{13}$. From such centres there would have been an intense discharge of toxic elements and hydrogen into deep basins. In such an environment, one would have expected only the most simple and versatile life forms to survive.

Runcorn ${ }^{14}$ has discussed the possibility of quantised changes in mantle convection associated with cooling. If cells have become larger with time, then the current convection pattern may have been necessary for the recent biological diversifications. Fluctuating environmental pollution caused by closely spaced centres of intense submarine volcanism may have inhibited complex biological evolution for most of earth history.

Department of Geology,

W. S. FYFE

University of Western Ontario,

London, Ontario, Canada

Received 1 April; accepted 26 April 1977

Sakata, A., Nakagawa, N., Iguchi, T., Isoke, S., Morimoto, M., Hoyle, F. \& Wickramasinghe, N. C. Nature 266, 241 (1977).

Hoyle, F. \& Wickramasinghe, N. C. Nature 266, 241 (1977).

3 Chamberlain, W. M. \& Marland, G. Nature 265, 135 (1977).

4 Hargraves, R. B. Science 193, 363 (1976).

Dimroth, E. \& Kimberley, M. M. Can. J. Earth Sci. 13, 1161 (1976).

Margulis, L., Walker, J. C. G. \& Rambler, M. Nature 264, 620 (1976).

Baker, A. R., Gass, I. G. \& Neary, C.
Fyfe, W. S. Gensci. Can. 3, $82(1976)$

Fyfe, W. S. Gensci. Can. 3, 82 (1976). R. Earth planert Sci. Letr. 30,1 (I976). in the Red Sea (eds Degens \& Ross), 272 (Springer-Verlag, New York,

(1974)

Andrews, A. J. \& Fyfe, W. S. Geoscience, Canada 3,84 (1976).

Krauskopf, K. B. Introduction to Geochemistry (McGraw-Hill, London, 1967).

Fyfe, W. S. Nature 249, 338 (1974).

Runcorn, S. K. Phil. Trans. R. Soc. A258, 228 (1965).

\section{Interaction between effects}

of vesicular-arbuscular mycorrhiza and fertiliser phosphorus on yields of potatoes in the field

MANY experiments in controlled environments have shown that vesicular-arbuscular (VA) mycorrhizas may benefit the phosphorus uptake and growth of plants ${ }^{1-4}$, depending on the nature and level of indigenous inoculum, the phosphorus status of the soil and other factors ${ }^{5-7}$. But there have been few reports of attempts to obtain larger crops, or reduce phosphorus fertiliser requirement, by manipulation of VA mycorrhizal infection in field $\mathrm{crops}^{8-12}$. We report here the effect on potatoes of an artificial increase in the level of VA infection. Potatoes are known to have VA mycorrhizas ${ }^{13-16}$, and their sparse rooting systems ${ }^{17}$ and heavy phosphorus demand suggest that they should respond to infection. This is the first report of a successful field inoculation experiment on a major field crop in temperate zone conditions.

The method of inoculation depended on observations, made in a separate experiment, on the changes of spore number and extent of infection caused by different cropping sequences. Cropping with cereals tended to induce high spore density, with heavy infection of subsequent crops, whereas if the area was left fallow there was a rapid decline in spore density and subsequent level of infection (Table 1).

The potato experiment was sited on an area left fallow for $2 \mathrm{yr}$, so that the spore density was only about one per $\mathrm{ml}$. The inoculum consisted of topsoil from nearby plots, 